\title{
An Analysis on the Commercial Insurance Demand in Qingyang
}

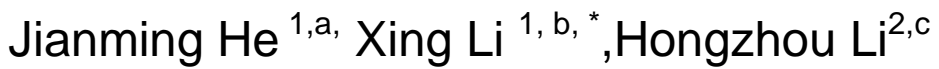 \\ ${ }^{1}$ College of Economic and Management, Longdong University, Gansu, Qingyang 745000, China \\ ${ }^{2}$ Qingyang Central Branch,NEW CHINA LIFE INSURANCE COMPANY LTD,745000,China

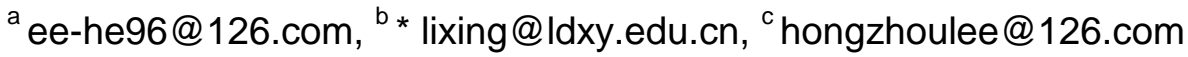

Keywords: Qingyang; Commercial insurance; Effective demand

\begin{abstract}
Based on the analysis of current demand for commercial insurance in Qingyang, this paper investigated the main factors affecting consumers to cover commercial insurance with questionnaires, and proposes countermeasures of optimizing the market structure, expanding marketing channels and raising income levels to promote effective demand for commercial insurance in Qingyang.
\end{abstract}

\section{Introduction}

Chinese insurance industry has progressed rapidly since its recovery in 1980, but still lags behind the overall standard of international insurance industry [1]. As a prefectural-level city of Gansu province, Qingyang is relatively underdeveloped economically, but its insurance market is full of promise and ready to be explored [2]. Nevertheless, on one hand, consumers lack of insurance awareness and have some misunderstandings of insurance industry[3], on the other hand, Qingyang insurance market lacks of main players and has a limited coverage area of services, therefore, consumer's effective demand cannot be further increased and the commercial insurance industry lacks of motivation while developing[4]. Consequently, it is of great significance to probe into the factors and countermeasures that influence the commercial insurance demand in Qingyang.

\section{Status Quo of Commercial Insurance Demand in Qingyang.}

Over the past decade, remarkable achievements has been made in the development of commercial insurance in Qingyang, the market scale has constantly expanded, the premium income has increased, and the index of insurance intensity as well as penetration has also improved

1.Premium Income Increased Constantly

Based on the analysis of premium income of original insurance in Qingyang, the author found that the effective demand for commercial insurance in Qingyang increases year by year, which mainly are demand for property insurance and life insurance.

Chart 1 indicates the premium income of original insurance and the income structure of Qingyang from 2006 to 2015. The premium income of original insurance has increased from 257.756 million yuan in 2006 to 1800.3805 million yuan in 2015, with a net premium increase of 1542.6245 million yuan, and the annual increase rate of premium over the past decade is about $24.10 \%$.Demands for property, life, accident and health insurance have also increased significantly in recent years.

Chart 1 Premium income of Original Insurance in Qingyang from 2006 to 2015

\begin{tabular}{cccccc}
\hline Year & $\begin{array}{c}\text { Premium income of } \\
\text { Original Insurance }\end{array}$ & Property Insurance & Life Insurance & $\begin{array}{c}\text { Accident } \\
\text { Insurance }\end{array}$ & Health Insurance \\
\hline 2006 & 25775.60 & 8046.03 & 16669.37 & 702.22 & 357.98 \\
2007 & 31423.97 & 11021.78 & 19317.00 & 715.19 & 370.00 \\
2008 & 47622.02 & 13110.37 & 32801.64 & 951.49 & 758.52 \\
2009 & 54748.45 & 16061.45 & 36303.23 & 1039.74 & 1344.03 \\
2010 & 77068.91 & 25236.83 & 47999.39 & 1421.31 & 2411.38 \\
2011 & 84630.89 & 30578.71 & 48251.34 & 2109.10 & 3691.74 \\
2012 & 96634.24 & 39217.73 & 50394.43 & 2006.81 & 5015.27 \\
2013 & 114414.35 & 48373.33 & 57059.75 & 2595.87 & 6385.40 \\
2014 & 133575.02 & 55832.22 & 66849.87 & 2911.08 & 7981.85 \\
2015 & 180038.05 & 62564.59 & 102462.47 & 3834.54 & 11176.45 \\
\hline
\end{tabular}


Note: Data was collected from the official website of China Insurance Regulatory Commission, Gansu Bureau.

The Intensity and Penetration of Insurance Improved constantly

In recent years, the intensity and penetration of insurance has improved gradually in Qingyang.

Based on the local permanent resident population and the GDP index, Chart 2 indicates that insurance intensity in Qingyang (premium/ permanent resident population) has increased from 382.73 yuan per person in 2011 to 807.60 yuan per person in 2015, with an annual increase rate over 15\%, and the increase rate of 2015 even reached $34.43 \%$, the overall growth has doubled within five years. Meanwhile, insurance penetration (premium income/GDP) has improved steadfastly, which shows that the status of Qingyang commercial insurance industry in national economy has been stabilized and is on an uptrend.

Chart 2 Insurance Intensity and Penetration in Qingyang from 2011 to 2015

\begin{tabular}{ccccc}
\hline Year & $\begin{array}{c}\text { Permanent } \\
\text { population(10,000 } \\
\text { person) }\end{array}$ & $\begin{array}{c}\text { GDP(100 million } \\
\text { yuan) }\end{array}$ & $\begin{array}{c}\text { Insurance } \\
\text { Intensity(yuan) }\end{array}$ & $\begin{array}{c}\text { Insurance } \\
\text { penetration(\%) }\end{array}$ \\
\hline 2011 & 221.12 & 454.08 & 382.73 & 1.86 \\
2012 & 221.84 & 534.10 & 435.60 & 1.81 \\
2013 & 222.27 & 616.50 & 514.75 & 1.86 \\
2014 & 222.35 & 668.93 & 600.74 & 2.00 \\
2015 & 222.93 & 609.44 & 807.60 & 2.95 \\
\hline
\end{tabular}

Note: from data of the economic performance of Gansu province and Qingyang during 2011 to 2015.

\section{Main Factors affecting the Demand for Commercial Insurance in Qingyang}

Consumer Factors. In order to explore the main factors affecting the demand for commercial insurance in Qingyang, the author has made a questionnaire survey in counties of Qingyang. The Questionnaire was designed by the author and has questions regarding consumer's understanding of commercial insurance, consumption willingness, and ways of investing the capital etc. 300 questionnaires were issued to consumers living in the seven counties and one district of Qingyang during March 19th and 20th, 2016, all questionnaires were withdrew, and the valid response rate was $100 \%$.

After collecting and sorting the data, we found that only 58 respondents covered commercial insurance, while the rest 242 respondents were not, and the coverage rate of insurance was only $19.3 \%$. In order to have a deeper understanding of the activities of Qingyang consumers attending commercial insurance, the author has made a deep analysis of the questionnaire, and the result shows that there are three main reason affecting Qingyang people's consuming behavior of commercial insurance.

Lack of Insurance awareness According to the statistics, 116 respondents indicate that they have some knowledge of commercial insurance classification, which only account $38.67 \%$ of the overall respondents, while the rest 184 respondents say they don't have, which account $61.33 \%$.

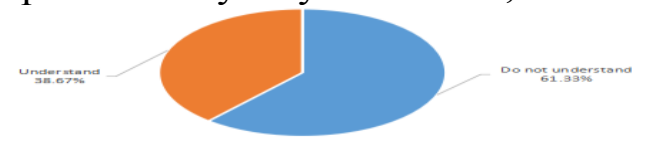

Pie Chart 1 Percentage of respondents who know the commercial insurance classification

Furthermore, as pie chart 2 illustrates, 166 respondents think it is of necessity to cover commercial insurance, which accounts $55.33 \%$ of the overall number, while there are still 134 respondents think it is not necessary, which takes up $44.67 \%$.

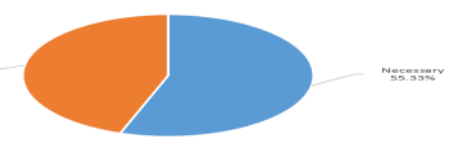


Pie Chart 2 Percentage of respondents who think it's necessary to cover commercial insurance

Last but not the least, there are 45 respondents, which accounts $15 \%$ of the total respondents, deem commercial insurance as an investment vehicle, 198 respondents, which accounts $66 \%$, think that commercial insurance safeguards insurer's property and life, while there are 30 respondents which takes up $9 \%$ of the total number think that commercial insurance would cheat people's money; and there are 27 respondents have any idea of commercial insurance, which accounts $9 \%$.

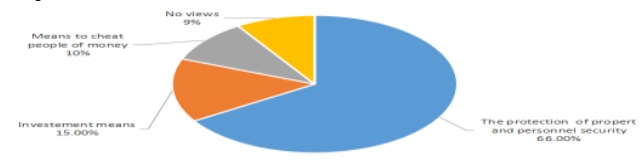

Pie Chart 3 Percentage of respondents' understanding of commercial insurance

According to the statistics above, most of the consumers in Qingyang lack of sufficient knowledge about commercial insurance and understanding of the necessity of covering commercial insurance. Although most of the respondents have a positive attitude toward commercial insurance, there are still some people have prejudice against or misunderstand commercial insurance. To conclude, the insurance awareness of consumers in Qingyang is of urgent need to be raised.

Limited Income. Literatures have proved that income level is a major factor influencing the demand of commercial insurance, and two of them are positively related [5]. According to the Maslow's Need-hierarchy Theory, consumer will have higher level of demand once his basic physical demands are fulfilled. Therefore, as their income increased, consumers in Qingyang will considerate the safety issue and consequently spurred the effective demand for commercial insurance. The economy of Qingyang has developed significantly in recent years, the disposable income of urban residents and net income of rural residents also increased continuously, however, compared with the provincial or national economic development, Qingyang's economy still falls behind and the income level is still relatively low, which could not provide a sound foundation for increasing the demand for commercial insurance. Chart 3 shows the income of the nation, Gansu province and Qingyang accordingly from 2010 to 2015 which indicates the income gap expands year by year.

\begin{tabular}{|c|c|c|c|c|c|c|}
\hline & \multicolumn{3}{|c|}{$\begin{array}{c}\text { Per capita disposable income of urban } \\
\text { residents }\end{array}$} & \multicolumn{3}{|c|}{ Per capita net income of rural residents } \\
\hline & Nation & Gansu & Qingyang & Nation & Gansu & Qingyang \\
\hline 2010 & 19109 & 13189 & 12453 & 5919 & 3424 & 3154 \\
\hline 2011 & 21810 & 14989 & 14388 & 6977 & 3909 & 3673 \\
\hline 2012 & 24565 & 17157 & 16662 & 7917 & 4507 & 4262 \\
\hline 2013 & 26955 & 18965 & 18761 & 8896 & 5108 & 4888 \\
\hline 2014 & 29381 & 20804 & 20637 & 9892 & 5736 & 5499 \\
\hline 2015 & 31195 & 23767 & 23426 & 11422 & 6936 & 6945 \\
\hline
\end{tabular}

Note: the data was collected from the official website of State Stastics Bureau, Stastics Bureau of Gansu Province and Statistic Bureau of Qingyang.

Pie chart 4 shows the percentage of reasons why consumers don't cover commercial insurance. $43 \%$ of consumer chose the reason of having limited income. So it is clear that limited income is a major reason for insufficient effective demand for commercial insurance.

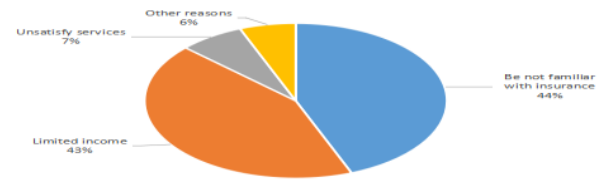

Pie Chart 4 reasons for consumers not covering insurance

Outmoded Financial Management ideas. consumers in Qingyang still hold a relatively conservative attitude towards finance management, and their ways of managing the wealth mainly are depositing, investing in stock, funds or real estates, few people invest in commercial insurance. 
Statistics from the questionnaire regarding consumers' way of financial management shows that over half of the consumers choose to deposit spare money in banks, which accounts for $54 \%$, and $18 \%$ of consumer choose to buy stocks or national debt; $7 \%$ choose to invest money in real estate market, and nearly $10 \%$ choose other ways of investment. However, only $1.33 \%$ of consumer view commercial insurance as an investing tool and would like to buy it, and the result can be illustrated by pie chart 5 . As the survey finding indicates, consumers in Qingyang are deeply influenced by traditional financial management ideas and prefer to deposit money in bank, therefore squeezed consumers' demand for commercial insurance.

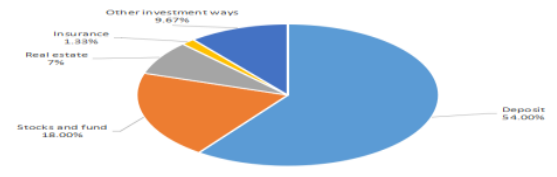

Pie Chart 5 Percentage of financial management ways

Supplier Factors. Lack of Dominant Market Players. Currently, the number of commercial insurance company in Qingyang has increased from only one which is PICC to eighteen, and 10 of them are property insurance companies, and eight life insurance companies in total. However, according to the statistics from the official website of CIRC and website of CIRC Gansu Bureau, there are 152 commercial insurance companies in China's insurance market, 71 of them are property insurance companies and 81 are life insurance companies. While there are only 25 commercial insurance companies in Gansu province, 12 of them are property insurance companies and 13 are life insurance companies. Obviously, the number of dominant players in the insurance market of Qingyang and of Gansu province is still relatively small when it is compared with that of the whole nation. Limited number of dominant players constrains the expansion of insurance market and could not create an environment of consuming insurance, therefore has negative effects on consumer's buying willingness for commercial insurance.

Limited coverage range of Insurance Company's Services. The number of branches set in counties of Qingyang by insurance companies are unevenly distributed, therefore the range of insurance services mainly concentrated in Xifeng district, while there are relatively few branches in the rest of seven counties. Insurance products and services offered by each company are different from each other, and consumer's demands also differentiate. When there are not enough insurance companies in the market or the market is monopolized by one insurance company, then consumer's demands cannot be well fulfilled and their effective demand for commercial insurance would be constrained consequently.

Chart 4 distribution of property insurance companies and branches in Qingyang

\begin{tabular}{cccccccccc}
\hline & $\begin{array}{c}\text { Xifeng Qingcheng } \\
\text { District county }\end{array}$ & $\begin{array}{c}\text { Huan } \\
\text { County }\end{array}$ & $\begin{array}{c}\text { Huachi } \\
\text { County }\end{array}$ & $\begin{array}{c}\text { Heshui } \\
\text { County }\end{array}$ & $\begin{array}{c}\text { Zhengning } \\
\text { county }\end{array}$ & $\begin{array}{c}\text { Ning } \\
\text { County }\end{array}$ & $\begin{array}{c}\text { Zhenyuan } \\
\text { County }\end{array}$ & Total \\
\hline PICC & 7 & 3 & 2 & 3 & 3 & 3 & 4 & 5 & 30 \\
China Continent & 1 & 1 & - & 1 & - & - & 1 & - & 4 \\
China United & 2 & 1 & 1 & 1 & - & - & 1 & 1 & 7 \\
Pacific & 1 & - & 1 & - & - & - & - & - & 2 \\
Ping An & 1 & 1 & 1 & - & - & - & 1 & - & 4 \\
Tian An & 1 & - & 1 & - & - & - & - & 1 & 3 \\
Yong An & 1 & 1 & 1 & 1 & - & - & 1 & 1 & 6 \\
Sunshine & 1 & - & 1 & - & - & 1 & - & - & 3 \\
Life & 1 & 1 & 1 & - & 1 & - & 1 & 1 & 6 \\
An Bang & 1 & - & - & - & - & - & - & - & 1 \\
Total & 17 & 8 & 9 & 6 & 4 & 4 & 9 & 9 & - \\
\hline
\end{tabular}

Note: Data was collected from the official website of China Insurance Regulatory Commission, Gansu Bureau 
Chart 5 Distribution of life insurance companies and their branches in Qingyang

\begin{tabular}{|c|c|c|c|c|c|c|c|c|c|}
\hline & $\begin{array}{c}\text { Xifeng } \\
\text { District }\end{array}$ & $\begin{array}{l}\text { Qingcheng } \\
\text { county }\end{array}$ & $\begin{array}{l}\text { Huan } \\
\text { County }\end{array}$ & $\begin{array}{l}\text { Huachi } \\
\text { County }\end{array}$ & $\begin{array}{l}\text { Heshui } \\
\text { County }\end{array}$ & $\begin{array}{c}\text { Zhengning } \\
\text { county }\end{array}$ & $\begin{array}{c}\text { Ning } \\
\text { County }\end{array}$ & $\begin{array}{c}\text { Zhenyuan } \\
\text { County }\end{array}$ & Total \\
\hline Pacific Life & 1 & 1 & 1 & 1 & - & 1 & 1 & 1 & 7 \\
\hline Ping An Life & 1 & 1 & 1 & - & - & - & 1 & 1 & 5 \\
\hline $\begin{array}{l}\text { Tai Ping } \\
\text { Life }\end{array}$ & 1 & - & - & - & - & - & - & - & 1 \\
\hline Ping An & 1 & - & - & - & - & - & - & - & 1 \\
\hline PICC & 1 & 1 & 1 & 1 & - & - & 1 & 1 & 6 \\
\hline $\begin{array}{l}\text { Sunshine } \\
\text { Life }\end{array}$ & 1 & - & - & - & - & - & - & - & 1 \\
\hline $\begin{array}{c}\text { New China } \\
\text { Life }\end{array}$ & 1 & - & - & - & - & - & - & - & 1 \\
\hline Total & 14 & 9 & 7 & 6 & 3 & 6 & 17 & 15 & - \\
\hline
\end{tabular}

Note: Data was collected from the official website of China Insurance Regulatory Commission, Gansu Bureau

Chart 4 and Chart 5 respectively show the distribution of the 10 property insurance companies and the 8 life insurance companies and their branches in Qingyang. Among these, only the branches of PICC Property and Casualty Company Limited and China Life Property and Casualty Insurance Company Limited evenly locate in the seven counties and one district of Qingyang, while the other insurance companies only distribute in parts of the counties and the number of branches are relatively inadequate.

Lack of Insurance Professionals and Intermediary Agencies. First of all, China's insurance industry now has a weak foundation and is still in its primary stage, and there are many problems in the building of insurance talent pool [6]. Currently, the insurance market of Qingyang has not established a database concerning the amount and type of insurance professionals, but according to the reality that insurance companies are making efforts to introducing talents and building their talent pools, we can tell that the demand for insurance professional is quite strong.

Secondly, there are limited amount of intermediary agencies of commercial insurance in Qingyang which serve as a strong supplement for insurance company, and the services delivered by them are not satisfying. Currently, there hasn't been any insurance agents in Qingyang commercial insurance market, and insurance brokers mainly are banks. However, the banks usually has a poor service attitude, and could not explain products to consumers clearly, what's more, they even obscure the relationship between risks and benefits of the product, so that consumers are misled and confused, and turns a skeptical attitude toward commercial insurance.

\section{Countermeasures to Improve the Demand for Commercial insurance in Qingyang}

Optimizing the Market Structure and Increasing Market Players. In order to optimize the insurance market structure of Qing yang, it is necessary to balance the development of insurance market of both rural and urban regions, to increase market players and to refine the insurance agencies by setting up branches, marketing outlets, insurance agents and brokers in places like Zhengning county and Heshui county, where insurance companies are scarce. Besides, it's essential to form a multi-layered market structure and diversify the insurance market by encouraging the development of small and medium-sized insurance company in Qingyang, and helping market players of different size to have their own comparative advantages.

Broadening the Marketing Channels and Refining the Service Networks. The strategy of broadening marketing channels should combine the traditional way of selling through its own channels with the way of indirect marketing by insurance agents and brokers, and insurance companies should especially strengthen their cooperation with banks. Being allied with banks, insurance companies should further optimizing the bilateral cooperation and the marketing process, 
allocating respective resources reasonably, saving the transaction fee and cost, so that insurance products will gain price advantage and attract consumers to invest. Meanwhile, it is important to take the demand of remote regions into consideration, making sure that where there is demand, there is supply.

Advertising Efforts of Insurance Company and Guidance Role of News Media. Insurance companies should step up their efforts to popularize insurance knowledge to the public and raise their awareness of covering insurance. There are many ways of advertising, first of all, insurance companies can advertise thorough platforms like magazine, radio stations, news, internet, social media and outdoor LED screens. Secondly, to dispatch pamphlets during festivals or holidays to consumers on street and have face-to-face communications with them. Thirdly, to engage in public welfare activities moderately so as to change consumers attitude toward commercial insurance.

Meanwhile, news media should also play its advertising to set up correct ideas of investing insurance and supervisory role proactively to stabilize the market and provide a healthy and safe investing environment [7] which will in turn increasing consumers' willingness of covering insurance.

Strengthening Talents Training and Improving Service Quality. Threshold for employees working in insurance industry should be moderately raised, and the insurance market should make efforts to introduce professionals such as insurance management staff, insurance marketing staff and accountants, and to increase trainings for current staffs, enhancing their knowledge reserves, improving their service quality and attitude which centers on customers [8].

\section{Promoting Economic Growth and Increasing People's Income.}

The rise of Qingyang consumers' income level are motivated by the development of Qingyang's overall economy which requires Chinese government, Gansu Provincial government and Qingyang municipal government to put economic development at the first place [9]. Consequently, a constant economic growth and uprising income level would drive up the demand for insurance.

Finally, in the face of consumers' various demands, insurance companies should moderately innovate and diversify their insurance products. What's more, companies should also change their old-fashioned operating ideas which centers on self-benefits, focusing on consumers' interests and building up long-term insurance relationship with consumers so that the demand for insurance could increase steadfastly.

\section{Conclusion}

Commercial insurance is an essential part of social security system and plays an important role in securing consumers' basic life and stabilizing the society, while significant development of commercial insurance in Qingyang is mainly motivated by the effective demand of consumers, therefore, importance should be attached to factors that influence the effective demand for commercial insurance and existing problems. What's more, detailed plans should be made, practiced and refined so that commercial insurance could play a greater role in the national economy and the social development.

\section{Reference}

[1] TU Dongyang. Research on the relationship between regional insurance industry and its development in China[D]. Wuhan: Doctoral Dissertation of Wuhan University, 2014:41-44.

[2] ZHONG Shuiying, LI Qiangyi, XIAO Pan. The regional difference of the development level of China's insurance industry and its distribution dynamic evolution[J]. Insurance Research, 2016(3):3-17. 
[3] LI Yanxin. Research Report On Consumer awareness and acceptance of Insurance[D]. Beijing: Master's degree thesis of Capital University of Economics and Business, 2015:3-4.

[4] Li X., Qu T., He J.M., Hou B.J.,Seek Excellence on the Hospital Quality Management Competition[J],Basic \& Clinical Pharmacology \& Toxicology,2016 ,December, Volume 119, Issue S4,HHME16-H24

[5] JIANG Caifang, KANG Junhua. Insurance market situation and development strategy in western area of Hunan [J]. Journal of Jishou University (Natural Science Edition), 2009(7): 117-121..

[6] Li, Xing; Jia, Ying, Financial industry support develops the analysis of influence on small and medium enterprises: In Northwest Gansu, China[J],ACSR-Advances in Comptuer Science Research 2016,(37),pp:2088-2091

[7] ZHOU Yi. Research on the current situation of the market demand of insurance talents and the cultivation of Applied Talents [J]. Finance and Insurance, 2013(8):132-133.

[8] Li,Xing; YangZihan; HouBingjie, Analysis of Internal and External Factors Affecting the Development of Cross-Strait Cultural and CreativeIndustries [J],Advances in Social Science Education and Humanities Research.2016,(77)pp:151-155

[9] CHEN Xiaoyi. Research on the influence of income level on Insurance Demand -- Based on the empirical analysis of 31 provinces and cities in China [J]. Modern Trade and Industry, 2007(12):46-47.

[10] Xing Li, Qiu Wenhong, Zhang Peiyao, and. Discussion on service innovation of cultural and Creative Park: cultural value perspective [J]. macroeconomic management, 2017, (S1): 34-36. 